\title{
Darwin, Beetles and Phylogenetics
}

\section{Rolf G. Beutel ${ }^{1} \cdot$ Frank Friedrich $^{1,2} \cdot$ Richard A. B. Leschen $^{3}$}

1) Entomology group, Institut für Spezielle Zoologie und Evolutionsbiologie mit Phyletischem Museum, FSU Jena, 07743 Jena; e-mail: rolf.beutel@uni-jena.de; ${ }^{2)}$ Biozentrum Grindel und Zoologisches Museum, Universität Hamburg, 20144 Hamburg; ${ }^{3)}$ New Zealand Arthropod Collection, Private Bag 92170, Auckland, NZ

Whenever I hear of the capture of rare beetles, I feel like an old warhorse at the sound of a trumpet. Charles R. Darwin 


\section{Abstract}

Here we review Charles Darwin's relation to beetles and developments in coleopteran systematics in the last two centuries. Darwin was an enthusiastic beetle collector. He used beetles to illustrate different evolutionary phenomena in his major works, and astonishingly, an entire sub-chapter is dedicated to beetles in "The Descent of Man". During his voyage on the Beagle, Darwin was impressed by the high diversity of beetles in the tropics and expressed, to his surprise, that the majority of species were small and inconspicuous. Despite his obvious interest in the group he did not get involved in beetle taxonomy and his theoretical work had little immediate impact on beetle classification. The development of taxonomy and classification in the late $19^{\text {th }}$ and earlier $20^{\text {th }}$ centuries was mainly characterised by the exploration of new character systems (e.g., larval features, wing venation). In the mid $20^{\text {th }}$ century Hennig's new methodology to group lineages by derived characters revolutionised systematics of Coleoptera and other organisms. As envisioned by Darwin and Ernst Haeckel, the new Hennigian approach enabled systematists to establish classifications truly reflecting evolution. Roy A. Crowson and Howard E. Hinton, who both made tremendous contributions to coleopterology, had an ambivalent attitude towards the Hennigian ideas. The Mickoleit school combined detailed anatomical work with a classical Hennigian character evaluation, with step wise tree building, comparatively few characters, and a priori polarity assessment without explicit use of the outgroup comparison method. The rise of cladistic methods in the 1970s had a strong impact on beetle systematics. Cladistic computer programs facilitated parsimony analyses of large data matrices, mostly morphological characters not requiring detailed anatomical investigations. Molecular studies on beetle phylogeny started in the 1990s with modest taxon sampling and limited DNA data. This has changed dramatically. With very large data sets and high throughput sampling phylogenetic questions can be addressed without prior knowledge of morphological characters. Nevertheless, molecular studies have not lead to the great breakthrough in beetle systematics - yet. Especially the phylogeny of the extremely species rich suborder Polyphaga remains incompletely resolved. Coordinated efforts of molecular workers and of morphologists using innovative techniques may lead to more profound insights in the near future. The final aim is to develop a well founded phylogeny which truly reflects the evolution of the immensely species rich group of organisms. 


\section{Introduction}

Beetles are conspicuous and often attractive insects, and as a group, they were named by Aristotle in the fourth century BC (Crowson 1981) and correctly characterised as insects with wingcases (gr. koleon = sheath), the main criterion for the definition of Coleoptera in the glossary of the Origin of Species (Darwin 1859: p. 673). Much earlier than Aristotle's treatment of beetles in the "Historia Animalium," species of the genus Scarabaeus enjoyed a sacred status in ancient Egypt (e.g., Darwin 1859: p. 187), symbolizing resurrection, self-creation, and metamorphosis. The latter aspect was resumed in Franz Kafka's gloomy narrative "Die Verwandlung" ("The metamorphosis"), with his protagonist Gregor Samsa transformed into a huge insect, addressed as an "old dung beetle" by a charwoman.

Many beetle species, notably, representatives of the families Carabidae (ground and tiger beetles), Scarabaeidae (scarab beetles), Buprestidae (jewel beetles), and Coccinelidae (ladybird beetles) are strikingly beautiful. This explains partly why beetles, aside from butterflies, have always been favourite objects of collectors, among them numerous amateurs, but also highly prominent figures in biology such as Carolus Linnaeus and Charles Darwin. Another, more practical reason for collecting beetles, is that they are easier to collect, maintain, and curate without post-mortem damage to specimens (Marren 2008), not having the fragile wings of Lepidoptera and not loosing colour after death.

Compared to Diptera, beetles play a very minor role with respect to the health of humans and their life stock. However, the economic impact of certain groups is tremendous. Many species, especially members of the families Chrysomelidae (leave beetles), Curculionidae (weevils) and Tenebrionidae (darkling beetles), can cause great damage to cultural plants and stored products. This is partly compensated by beetles considered as beneficial as predators of aphids and other pest insects, the most important of them being Coccinellidae. This is a group also popular in the folklore and poetry of many countries, and known by common names related to the Virgin Mary (e.g., ladybird, Marienkäfer), Moses (Moshe Rabbenu's little cow), or Freyja, the nordic goddess of fertility (Freyjafugle), but also names without religious affiliation such as Mutschekiepchen, which is used in some regions of Germany. It is less commonly known that beetles and their larvae play a considerable role as food source in different parts of the world, and historically also in Central Europe. During the Thirty Years' War large larvae of Cerambycidae and other groups were used by starving people in many regions of what is Germany today.

Beetles belong to the oldest groups of holometabolous insects as documented by the fossil record. They are represented by a fair number of well preserved specimens in the Permian (e.g., Ponomarenko 1969), and explosive radiations took place in the Mesozoic (e.g., Crowson 1981; Ponomarenko 1977), perhaps in association with the rise of angiosperms in the Cretaceous. One of their most intriguing aspects is their extreme diversity. With approximately 360.000 known species beetles are by far the largest group of organisms on a comparable taxonomic level (Grimaldi and Engel 2005). An "inordinate fondness for beetles" was allegedly ascribed to the Creator ("if he exists") by the Scottish-Indian geneticist and evolutionary biologist John B. S. Haldane, (who also introduced an evolutionary unit he named the 'darwin' [Haldane 1949]). Considering all these and many other 
fascinating aspects of Coleoptera, it is not surprising that Charles Darwin, the founder of the evolutionary theory, greatly appreciated beetles as collector items (Desmond and Moore 1991) and as objects of study.

Here, rather than presenting a conspectus of the classifications of Coleoptera published since Linnaeus and Darwin (for this see Lawrence et al. 1995), our aim is to examine the role beetles played in Darwin's life and scientific work, to outline some of the major developments in the phylogenetic study of Coleoptera, and to give an abridged overview of scientists who have shaped beetle morphology and systematics since Darwin's time.

\section{Darwin and beetles}

Very early in his career as a naturalist, during his theological studies at Christ's college in Cambridge (1828-1831), Charles Darwin developed a deep passion for the study of beetles. In his time, this was by no means considered as an unusual or eccentric pastime. Probably as a response to the effects of the ugly industrial sprawl in the early $19^{\text {th }}$ century a virtual "beetle craze swept the nation" (Desmond and Moore 1991) and the collecting of insects, especially Coleoptera, was widely popular among his fellow students. His cousin, William Darwin Fox, was an early tutor in Coleopterology and inspired Darwin with his profound knowledge of the local flora and fauna and accompanied him on many collecting trips along the banks of the Cam, in the Jesus Ditch, and in the Midsummer Common (Desmond and Moore 1991). One anecdote relates how Darwin, in the stress of handling three supposedly rare beetles at a time, popped one of them in his mouth, a common practice of trained egg collectors of that time. The specimen, which was a bombardier beetle (Brachininae Carabidae), released exploding hydrochinones in Darwin's throat, which resulted in shock and the loss of all three specimens (Desmond and Moore 1991).

Darwin's coleopterological activities were not restricted just to collecting, mounting for display and the "ritual bragging among the beetle brotherhood" (Desmond and Moore 1991), but also included the demanding task of identifying beetles to species level. He relied on Samouelles "The Entomologist's useful Compendium" and other popular entomology books; but, as it was the case during his earlier medical studies at the University of Edinburgh, he was confronted with classificatory problems. Seeking clarity, he consulted the famous "Système des Animaux sans Vertèbres" by French Zoologist and Botanist Jean Baptiste de Lamarck, one of the leading works in evolutionary theory, (Desmond and Moore 1991).

In "The Voyage of the Beagle" (e.g., Darwin 1845 etc.) beetles were mentioned frequently and it would be beyond the scope of this study to cover this in detail. In chapter II he emphasised that the predacious ground beetles (Carabidae) (Fig. 1), carrion feeders, and Staphylinidae ("Brachelytra") were very rare in the tropics (compared to carnivourous "quadrupeds"), whereas phytophagous beetles of the groups "Ryncophora" (Rhynchophora s. Latreille 1825 [=Curculionidae]) and Chrysomelidae were very abundant. Darwin contemplated whether the "very numerous spiders and rapacious Hymenoptera supply the place of the carnivorous beetles". In chapter VIII Darwin mentioned the remarkable capture of a considerable number of terrestrial (Carabidae, Chrysomelidae, Scarabaeidae) and aquatic (Dytiscidae and Hydrophilidae) beetles in the open sea 17 miles off Cape Corrientes along the Pacific coast of Mexico, south of Jalisco, apparently more or less unaffected by 
the salt water. His assumption that the aquatic species were "floated into the sea by a small stream" is plausible, and there is also little doubt that the terrestrial ones had been blown by the wind, as he suggests, as other beetles may be captured far from land (Jones and Leschen 2008). Remarkably, Darwin noted the collection of a South American nitidulid from Phallales ("Stinkmorchel") and noted the similar occurrence of beetles in Europe, a group now known to be host-specific and world wide (Leschen 1999). An anectdote in chapter XII highlights the attitude of South American contemporaries towards early ventures in biodiversity research. Darwin told of an old Chilean lawyer, who upon being asked what he thought of the King of England sending people out to collect lizards and beetles, retorted that "No man is so rich as to send out people to pick up such rubbish".

On the Galapagos Islands (chapter XVII) Darwin collected 25 species belonging to 17 families. He pointed out that comparatively few insect or plant species belonging to many families may be a general pattern on the archipelago. Apparently several new genera were among the material collected, and among those already known, one or two were of American origin, and the others had a world wide distribution. Of the tenebrionids occurring on the Galapagos Islands, three flightless genera, which have undergone extensive adaptive radiation (Stomion, Blapstinus and Ammophorus), have been dubbed 'Darwin's darklings' (Finston et al. 1997).

In his 'Journal of Researches' Darwin made a noteworthy observation on the "general aspect of the Coleoptera" he collected in the tropics: "The number of minute and obscurely coloured beetles is exceedingly great ... I may mention, as a common instance of one day's (June 23rd) collecting, when I was not attending particularly to the Coleoptera, that I caught 68 species of that order. Among these, there were only two of the Carabidae, four Brachelytra (=Staphylinidae), 15 Rhyncophora (=Curculionidae), and 14 of the Chrysomelidae". Along the same lines he wrote in a letter to Prof. J. S. Henslow (Rio de Janeiro, May 18, 1832) (cited in Barrett 1977) that in contrast to the current opinion ("no small insects in the collections from the tropics" [in London]; Barrett 1977: p. 4) the tropical fauna does not only comprise large species, but also numerous, mostly small and inconspicuous beetles. He explicitly mentioned "Hydropori" (small diving beetles, Hydroporini), "Hygroti" (small diving beetles, Hygrotus, or related to this genus), "Hydrobii" (hydrophilid water beetles, Hydrobius or related genera), "Pselaphi" (tiny staphylinid pselaphines, "Palpenkäfer" [German]), "Staphylini" (Staphylinidae, rove beetles, family containing numerous small species), "Curculiones" (Curculionidae, weevils, most species rich beetle family containing mostly small species), and "Bembidia" (small riparian ground beetles, Bembidiini). As Darwin was apparently not interested in pursuing beetle taxonomy himself (see below), with regard to the newly discovered small species he urged entomologists in the letter "to look out and have their pens ready for describing". In the same letter to Henslow, Darwin illustrated his amazement with the tropical richness in smaller species with a specific collecting experience. In contrast to only three known species of the water beetle family Noteridae in Central and north western Europe (all of them belonging to the genus Noterus), he captured five distinct species of the group with "one haul" of his net.

The high tropical diversity of (mostly small) beetles observed by Darwin during his voyage on the Beagle was dramatically confirmed in the 1980s by Terry Erwin's famous diversity studies in the rain forests of the Amazon Basin (e.g., Erwin 1988). Erwin fogged individual tropical trees with lowimpact insecticides and counted several hundred arthropod species per tree, most of them belonging 
to Coleoptera. Erwin hypothesized a stunning number of 20-50 millions of insect species presently inhabiting this planet, but also a horrifying extinction scenario involving 20-30 millions species during our generation (Erwin 1988). The debate of how many species there are continues today (i.e., Novotny et al. 2007).

In Darwin's major theoretical works beetles play a moderate role compared to other groups such as pigeons, or even Lepidoptera, which are treated in a separate chapter of "The Descent of Man" (XI) (Darwin 1871). Nevertheless, in "On the Origin of Species" (Darwin 1859) beetles are mentioned quite frequently in different contexts. Morphological modifications of water beetles (e.g. fringed swimming legs) are used as an example for adaptations to a specific lifestyle and to the necessity to compete with other organisms in a similar environment (pp. 96, 114). Interestingly, the vestigial or completely reduced fore tarsi of dung beetles are discussed with regard to the question about whether accidental mutilations could be hereditary, and apparently Darwin was somewhat ambivalent in this crucial issue (p. 187: "the evidence... at present is not decisive" [!]). The wingless condition of many beetle species was ascribed to the reduced risk of "being blown to sea, and thus destroyed". It is noteworthy that Darwin explained the reduction of wings due to natural selection occurring in many successive generations, but considered the possibility that the Lamarckian factor of "disuse" may have played a role (p. 188: "combined probably with disuse" [!]). The parasitic and hypermetamorphic meloid genus Sitaris is mentioned in the context of how developmental changes could result in novel evolutionary changes (p. 615-616). Darwin discussed a scenario with a "new class of insects" emerging from such a specialised form, he emphasised that "the course of development of the new class would be widely different from our known insects" and that the agile first instar larva "would not represent the former condition of any adult and ancient form". It should be mentioned that in contrast to Darwin's view, the first larval stage of parasitic beetles, sometimes referred to as triungulins, is much closer to the "typical" coleopteran larval morphology, than the distinctly simplified following instars, which in the case of Sitaris feed on the provisions of the hosts, solitary bees of the genus Anthophora.

In chapter I of "The Descent of Man" (Darwin 1871) the vestigial wings under the fused elytra of Coleoptera was cited in the context of rudimentary organs. In chapter X, thesecondary sexual characters of beetles and other groups of insects such as "Thysanura" (in the sense of apterygote insects ["Smynthuridae"]], Diptera, Hemiptera, Homoptera, Orthoptera, Neuroptera, and Hymenoptera. Coleoptera) were discussed in some detail. In the subchapter "Order, Coleoptera (Beetles)" he discussed the sexually dimorphic colour patterns in Cerambycidae (e.g., "Prionidae", Rhagium) and other groups (e.g., Cantharidae, Meloidae) and horns occurring in males of different groups of Scarabaeoidea (e.g., Copris, Onthophagus), some weevils ("on the lower surface of the body"), and some Staphylinidae (Siagonium, Bledius). In the subchapter "Law of Battle," he quoted from Wallace's (1869) "The Malay Archipelago" an account of male beetles seemingly "ill-fitted for fighting" (Leptorhynchus angustatus, Curculionidae) that "nevertheless engage in conflicts for the possession of the females". Like Darwin, Alfred Russell Wallace was genuinely interested in Coleoptera. In a short study on tropical bark beetles he posed the stunningly modern question "whether the criminals are not really our benefactors - teaching us that there is something wrong, before we could otherwise perceive it". 
It is interesting that despite his profound interest in beetles, Darwin never pursued beetle taxonomy nor attempted to improve current classifications of Coleoptera (e.g., Latreille 1825). This is in contrast with his intensive taxonomic study of Cirripedia, a group of highly specialised crustaceans classified as 'fouling organisms' by modern marine scientists (e.g., Clare and Evans 2000), and certainly much less attractive than beetles from the point of view of an entomologist! Based on his investigation of barnacles (e.g., Darwin 1851) - praised as one of the most outstanding accomplishments in the whole field of systematic biology (Ghiselin 1991) - Darwin made valuable and surprisingly modern suggestions about how the practice of taxonomic work could be improved (Darwin 1859 [chapter 13]; Cain 1957; Simpson 1961; Mayr 1975). Like modern cladists, and in contrast to Linnaeus and Cuvier (Cain 1957), Darwin dismissed the a priori assessment of the importance of characters used for classifying organisms and promoted critical comparative study of species to identify suites of concordant characters to support phylogenetic relationships.

\section{J. M. C. Schiødte and early investigations of beetle larvae}

The Danish entomologist Jørgen M. C. Schiødte (1815-1884) was not only a contemporary of Darwin, but like him was elected honorary member of the Societé Entomologique de France in the same year (N. P. Kristensen, pers. comm.). Darwin cited Schiødte several times in "The Origin of Species", especially with respect to the evolution of subterranean species and eye reduction. In contrast to Darwin, Schiødte was deeply interested in the taxonomy of Coleoptera, which formed a major part of his work. He was the author of very important studies on beetle morphology and classification, including numerous treatments of beetle larvae under the collective title "De metamorphosi eleutheratorum observationes" (e.g., Schiødte 1862, 1883). These studies were mentioned a century after their appearance in "Imms General Textbook of Entomology" (p. 839) (Richard and Davies 1977 [cited from reprint of 1994]) as "the most important publications on the life-histories of these insects" (N. P. Kristensen, pers. comm.). Schiødte's remarkable work may be seen as a starting point of the detailed investigation of beetle larvae with a phylogenetic objective. Beetle larvae were usually ignored in Darwin's time and are still often neglected, even though their phylogenetic importance is generally recognised today (see below).

\section{The First and the Second Synthesis}

As pointed out by Lawrence et al. (1995) the classifications of beetles in the early and mid $19^{\text {th }}$ century (e.g., Latreille 1825, who based his classification on the number of tarsomeres) were non-phylogenetic like the simple arrangement of the 22 beetle genera in the 10th edition of Linnaeus' $18^{\text {th }}$ century "Systema Naturae". The publication of "On the Origin of Species" and subsequent general works on phylogeny and evolution (e.g., Brauer 1869; Haeckel 1896) had a long term influence on beetle systematics, but only a limited effect on taxonomic studies of the late $19^{\text {th }}$ century (Lawrence et al. 1995). A characteristic feature of the new classifications of the mid $19^{\text {th }}$ century was the concept of linear progression (Lawrence et al. 1995). This was summarised by Leng (1920) as follows: "The phylogenetic systems seek to arrange the families and series so that the more primitive beetles shall precede the more derivative; in such systems certain characters are assumed to indicate a stage in the progressive modification of the Coleoptera, rather than a relationship". This concept of scala 
naturae was also reflected in Ernst Haeckel's characteristic phylogenetic trees, which deliberately suggest a development from "lower forms" to "higher ones", with mammals and especially Homo sapiens as the climax of evolution (Fig. 2).

Beetle taxonomy and systematics of the early $20^{\text {th }}$ century were characterised by the inclusion of a wide range of new characters systems not used previously (e.g., Kolbe 1901). The attempt to develop classifications reflecting genealogical relationships (see Lawrence et al. 1995) was only partly successful due to the lack of new methods of phylogenetic reconstruction. Nevertheless, the effort of three prominent figures, the Belgian A. A. L. Lameere, the German H. J. Kolbe and the Austrian L. Ganglbauer resulted in great progress in beetle classification with many higher taxa that are still in existence, like the suborders Adephaga and Polyphaga. The result of the cooperative effort among these three scientists was referred to as "the first synthesis" by Lawrence et al. (1995).

The first half of the $20^{\text {th }}$ century was mainly characterised by extensive comparative studies across Coleoptera like Sharp and Muir (1912), and later Jeannel and Paulian (1944), who presented comprehensive studies on male genitalia. Forbes $(1922,1926)$ published extensive studies on wing venation and folding patterns and was first to consider the "ancestral" Archostemata (including the extremely specialised Micromalthus) as a separate suborder. Meanwhile, the study of larval stages initiated by Schiødte gained a strong momentum, with remarkable studies accomplished by Verhoeff (e.g., 1923), Bøving and Craighead (1931) (see above), and van Emden (e.g., 1932). Based on the increased amount of morphological data, a new classification was proposed by $\mathrm{P}$. de Peyerimhoff (1933), with the three suborders Archostemata, Adephaga, and Polyphaga, the latter divided into two large subunits, the Haplogastra (equivalent with Staphyliniformia) and the Symphiogastra (equivalent with Elateriformia and Cucujiformia). This achievement, together with R. A. Crowson's earlier works (see below) was referred to as "the second synthesis" by Lawrence et al. (1995).

\section{The German dipterist}

It is undisputed that the German entomologist Willi Hennig (1913-1976) had a tremendous impact on the biological sciences, arguably comparable to the effects of the Darwinian revolution in the $19^{\text {th }}$ century. Hennig's "Grundzüge einer Theorie der Phylogenetischen Systematik" (Hennig 1950) can be considered as the cornerstone of a fundamentally new approach in systematics. In contrast to the typological or essentialist concept prevailing since Linnaeus (and basically Aristotle) (see e.g., Mayr 1975), Hennig distinguished between morphological similarities that were either ancestral and do not denote evolutionary innovation and derived characters that do reflect natural, evolutionary relationships. His new precisely-defined concept of monophyly and the exclusive use of derived characters (apomorphies) for the reconstruction of phylogenetic branching patterns paved the way for classifications reflecting the evolution of groups of organisms, as envisioned by Darwin (1859), Haeckel (1866) and others.

Today, apart from some approaches in molecular systematics not based on parsimony (maximum likelihood, Bayesian analysis, see below), any serious phylogenetic work is rooted in Hennig's groundbreaking work in the 1950s (and in Darwin's idea of "descent with modification"). It is interesting that the acceptance of Hennig's novel approach was somewhat reluctant among systematists and taxonomists, especially in his native country. This was probably partly due to a 
linguistic barrier outside the German speaking scientific community, whereas in Germany conservatism and rigid hierarchical structures in the university system in the 1950s and early 1960s may have constrained acceptance of Hennig's approaches. The breakthrough of his methods came only after the publication of "Phylogenetic Systematics" (Hennig 1966), basically a distinctly shortened English version of the extensive first edition in German language (Hennig 1950).

Like Darwin, Hennig used different coleopteran taxa as examples in his theoretical work (e.g., Erotylidae, Dynastinae; Hennig 1950: pp. 49, 52). However, as a dipterist, he was not primarily interested in beetles. Considering the size and complexity of the group, Coleoptera were treated rather briefly in his "Stammesgeschichte der Insekten" (Hennig 1969). In the chapter 2.2.2.2.4.2. Coleoptera (Käfer) he points out numerous autapomorphies of beetles and emphasised the key role of the evolution of sclerotised fore wings, an evolutionary trend also seen in Paraneoptera and several groups of "lower neopteran" insects. He critically discussed the often used cliché of Coleoptera as the "most successful" order of insects, especially with respect to the criteria for success and the comparability between groups. Hennig argued that Coleoptera (probably + Neuropterida) were very likely the sistergroup of almost all other endopterygote lineages, and that they do not substantially surpass their counterpart in the endopterygote tree (Mecopteridae or Mecopterida + Hymenoptera) in terms of either species richness or ecological importance ("ökologische Valenz"). He discussed potential synapomorphies of Coleoptera and Neuropterida, and again in the second part of the chapter Palaeozoic beetle fossils. He emphasised that the Permian fossils assigned to Archostemata (Hennig used "Cupedidae" as a synonym) in traditional classifications (e.g., Ponomarenko 1969) do not share the apomorphies present in extant Archostemata, and should be placed in the stem-lineage of Coleoptera. This view was fully confirmed in a recent cladistic study on fossil and extant beetle lineages (Beutel et al. 2008).

A more contentious issue to mention here is the merit of absolute ranks in zoological systematics. In the first edition of his major work, Hennig (1950: pp. 202-290) attempted to create a scientific foundation for absolute categories based on geological age and that sistergroups bear the same rank. He later abandoned this concept (Hennig 1966) and many modern systematists agree on the impossibility of creating clear and falsifiable criteria for the Linnaean categories (e.g., Wägele 2001: p. 112). Their complete rejection was adamantly proposed by Ax (1987): "Linnaean categories are useless to identify the hierarchical levels of the phylogenetic system". This rigorous attitude does not take into account that this would mean to create a "plethora of names" (Minelli 1993) for numerous nested monophyla on many levels, especially in very large and complex groups. For the immensely species-rich Coleoptera (or Hexapoda as a whole) this would inevitably end in disorientation and drastically impede communication among biologists whose items of inquiry are species or lineages.

\section{Insect anatomy and Hennigian systematics}

Even though one of the most important insect morphologists of all times - Robert Evans Snodgrass (1875-1962) - was a US citizen, the detailed study of insect and beetle anatomy has apparently a stronger tradition in European countries. One of the most comprehensive studies of a single insect or beetle species is the monograph on Dytiscus marginalis (Korschelt 1923). This multi-authored, twovolume work covered in great detail external and internal structures of adults and larvae and is still 
tremendously useful today. It was the first and only monograph in a planned series which was supposed to cover well known animals of the European fauna.

The German entomologist Hermann Weber (1899-1956) was one of the most important morphologists of the $20^{\text {th }}$ century (Maier 2008). He was director of the Institut für Spezielle Zoologie at the University of Tübingen between 1951 until his untimely death in 1956. Among many other studies he published the beautifully illustrated entomological textbooks "Lehrbuch der Insektenkunde" and "Grundriss der Insektenkunde" (Weber 1933, 1938), which may arguably be considered as the German equivalents of Snodgrass' magnum opus "Principles of Insect Morphology" (Snodgrass 1935). Weber and his students produced outstanding works in insect morphology with anatomical illustrations of exceptional quality (e.g., Risler 1954). The aesthetic value and accuracy of the figures in Weber's posthumously published monograph on the elephant louse (Weber 1969) is a rare highlight in the study of insect morphology.

Weber was mainly interested in lice and beetles played a minor role in his works (e.g., Weber 1938). The only study dedicated to beetle morphology was by one of his students on the head structures of a weevil (Dönges 1954), a detailed descriptive study that lacked phylogenetic context. Weber was primarily a constructional morphologist ("Konstruktionsmorphologie"; Weber 1960) and had reservations against contemporary systematics (Maier 2008) and theoretical approaches in general, an attitude apparently widespread in the biological sciences during this time in Germany (G. Mickoleit, pers. comm.). In short, constructional morphology seeks to explain all morphologies in a given lineage based on functional constraints (see review in Reif et al. 1985), and does not seek to explain relationships based on shared-derived characters, like the methods of Hennig. Weber's aim was a new orientation of morphology as a synthesis based on evolution ("Neuorientierung der Morphologe ... [als] Synthese auf evolutionistischem Boden") (Weber 1955, 1960; see also Maier 2008), but emphasised that evolutionary preconditions ("Voraussetzungen") in morphology would encounter serious methodological objections ("schwere Bedenken methologischer Art") (Weber 1960; Maier 2008). He also pointed out that the ancestral form ("Ahnenform" [Grundplan; see Hennig 1950]) is inappropriate as a replacement for the morphological term "Typus" (Maier 2008). Weber considered that phylogenetic reconstruction was speculative, not based on hard evidence (i.e. fossils), and that the morphological information available by that time was insufficient. Consequently he obliged his $\mathrm{PhD}$ students to refrain from any phylogenetic conclusions in their theses (G. Mickoleit, pers. comm.). It is not known if Weber read Hennig's major work, but it appears rather unlikely, even though the book was available in the university library (Maier 2008). It was Gerhard Mickoleit (also University of Tübingen) who bridged the gap between Weber and Hennig and their different scientific approaches. Mickoleit's PhD thesis was carried out several years after Weber's death; nevertheless, he was strongly influenced by him and the Weberian influence on his detailed morphological investigation of the head of thrips is unmistakable (Mickoleit 1963). In the early 1970s Mickoleit was greatly inspired by three seminars held by Hennig at the University of Tübingen at the request of students. Mickoleit became one of the earliest protagonists of Hennig's ideas in Germany. Even though he never held a professorial position and did not give formal lectures, his teaching and his charisma revitalised insect morphology and systematics in Europe. Like Hennig and Weber, Mickoleit was not a coleopterist. However, he was a passionate beetle collector in his teens (new records for Polyphylla fullo and 
Nicrophorus germanicus for Schleswig Holstein are ascribed to him), and one of his comparative studies on the ovipositor of Coleoptera and Neuropterida yielded potential synapomorphies for these endopterygote lineages (Mickoleit 1973). The phylogeny of beetles, especially of Adephaga and the less diverse suborders Archostemata and Myxophaga, was one the favourite seminar topics discussed by Mickoleit, and in the 1970s he inspired an entire series of detailed studies on the morphology of larvae and adults of beetles (e.g., Baehr 1975; Burmeister 1976; Bils 1979; Beutel 1986; Tröster 1987; Belkaceme 1991). All these studies had a strong morphological and phylogenetic context with Hennigian character evaluation, though lacked explicit use of outgroup comparison and numerical analysis.

Another important school of insect morphology was based in Dijon, founded and led by J. R. Denis (N. P. Kristensen, pers. comm.). From this Dijon school, an important contribution on the evolution of coleopteran larval head structures - in the tradition of Schiødte and Bøving - was made by Bitsch (1966) along with several smaller studies of larvae published by other members of Denis's research group in the obscure journal with the remarkable title "Travaux du Laboratoire de Zoologie et de la Station Aquicole Grimaldi de la Faculté de Sciences de Dijon."

Lastly, a comprehensive contribution on beetle morphology by Larsén (1966) did not receive the attention it deserved after it was published. The title "On the locomotor organs of Gyrinidae" suggested that it would be strongly or exclusively focussed on whirligig beetles, one of the most specialised families of adephagan Coleoptera. In fact, the study was an extensive and thorough treatment of the thoracic morphology of beetles. The description and table of muscles of many adephagan and polyphagan beetles has been used in cladistic studies aiming at a clarification of the subordinal relationships of beetles (Beutel and Haas 2000; Friedrich et al. 2009).

\section{Two British coleopterists}

Two British entomologists of quite different disposition have made exceptional contributions to the knowledge of the classification and biology of Coleoptera. What they had in common was their ambivalent attitude towards the Hennigian principles in phylogenetics.

Very few coleopterists had a similar impact on the classification of beetles in the $20^{\text {th }}$ century than the exceptional English scholar Roy A. Crowson (1914-1999) (see above: second synthesis). The "lifelong Darwinist" (footnote in Crowson 1991) spent nearly his entire professional career at the Zoology Department of Glasgow University. He published more than 260 studies on beetles, proposed 142 taxa, and 13 taxa were named after him, among them the cryptic archostematan family Crowsoniellidae (see below). Crowson was a naturalist at the core and he published numerous small notes and observations on British beetles. Each room of his house was packed with books on many subjects, but most were shelves of fauna and flora. Aside from his biological pursuits and enormous literacy, like the above mentioned J. B. S. Haldane, he was an ardent socialist.

In the earlier stage of his scientific career, Crowson focussed on the natural history of British beetles, fungi, sagrine leaf beetle genera, and especially the study of the metendosternite (Crowson 1938, 1944), an internal character system which later turned out as extremely variable and almost useless for higher level classification in certain groups. However, the comparative study of this endoskeletal structure required complete dissection and disarticulation of specimens, which allowed 
Crowson to study in more detail other character systems useful for beetle classification. This led to his influential work published in the Entomologist's Monthly Magazine (e.g., Crowson 1950, 1954), his book on the natural classification published in 1955 (and reprinted in 1967), and an important review article in 1960. In these works Crowson builds on Peyerimhoff's (1933) classification but with an enormous number of taxa examined in adult and larval stages. Included in Crowson's work was the naming of a new suborder (Myxophaga), the use of Series (not be confused with misappropriated use of "series" in Hunt et al. 2007), new families, and the reshuffling of many higher taxa, especially in Elateriformia (Leschen and Beutel 2005) and Cucujiformia: the list of changes and new taxa is extensive (see Lawrence et al. 1995). These major works set the groundwork for more detailed studies in Dermestoidea (Crowson 1959), Cleroidea (e.g., Crowson 1964) and Cucujoidea (e.g., Crowson 1973), with many undescribed higher taxa occurring in the southern hemisphere, facilitated by Crowson's field work in the antipodes, especially Australia and New Zealand (e.g., Crowson 1995; Leschen 2000). These more specific works by Crowson and his students (especially Tapan Sen Gupta) are discussed elsewhere in more detail (e.g., Lawrence et al. 1995; Ślipiński and Pakaluk 1992).

Apart from Crowson's contributions to beetle systematics, he has published two other works that are outstanding achievements. His magnum opus, "The Biology of Coleoptera," is a detailed compendium of "all of the other stuff" that makes a beetle a beetle. Included are chapters on morphology (internal and external), natural history and ecology, behaviour, and physiology. Though cumbersome to use as a reference book, when scrutinised there is a wealth of information in Crowson (1981), and it is one of less then a handful of texts by a single author that treats all aspects of Coleopterology.

Crowson's intense interest in classifications led him to produce a landmark textbook on systematics published in 1970. Back then, while western society was undergoing a cultural revolution, it was the dawn of quantitative phylogenetics where taxonomists were developing a more rigorous and testable framework for producing classifications based on Hennigs ideas (see below). Crowson, too, believed that classifications should be phylogenetic anddeveloped them based on key characters that he felt were important, and in combination with diagnostic features. His evolutionary concept of taxonomy included adaptive zones, where representatives of one group gave rise to other lineages. This implies, of course, that his groups were not necessarily monophyletic in the Hennigian sense (Leschen and Beutel 2005). He did not subscribed to computerized methods, or for that matter, Hennig's formalised approach (Crowson 1970, 1982; Wheeler 1995). Of particular interest here, he believed that some molecular biologists were anti-darwinists (Crowson 1975), and he explicitly criticised "current cladistics" (Crowson 1991) (see The rise of cladistics and the Third Synthesis below). He pointed out that cladists seemingly "owe more to the 'numerical taxonomists' of a previous generation that (sic!) to the German dipterist" (i.e. W. Hennig). He particularly criticised the problematic determination of polarity in the characters used in cladistic studies, the "rejection of character weighting", and the neglect of fossils. Crowson's approach, which was outlined in his textbook and other studies, may have led to a certain degree of instability. This is documented by quite frequent "reshufflings" of groups in his classifications (see e.g., Leschen and Beutel 2005). 
In contrast to Crowson, the coleopterist and entomologist Howard E. Hinton (1912-1977) was not restricted to beetle systematics and evolution during the main part of his incredibly productive scientific career. Hinton was a curator at the Natural History Museum until 1949 and after that he was a Reader in Entomology, Professor of Entomology, and Professor of Zoology at Bristol University. He published more than 300 studies and was cited 72 times in Imm's General Textbook of Entomology (Richards and Davies, 1977 [reprint of 1994]). His research was more physiological in its general orientation and he covered fields like insect metamorphosis, respiratory adaptations, cryptobiosis, and his landmark "Biology of Insect Eggs" (Hinton 1981), which extensively used scanning electron microscope images as a comparative tool. However, like many other professional or non-professional entomologists (including Darwin) he started as a collector at an early age and (in contrast to Darwin) many of his earlier scientific studies were aimed at an improved classification of Coleoptera. Hinton was born in Mexico and in one of his first publications he recorded two beetle families new to the country (Hinton 1934), among them the mysterious Lepiceridae, now recognised as the sistergroup of the remaining families of the small suborder Myxophaga (Anton and Beutel 2006). In the 1930s and 40s, Hinton studied intensively the anatomy and taxonomy of groups assigned to Dryopoidea (Limnichidae, Elmidae, Dryopidae, Psephenidae) (e.g., Hinton 1940). His systematic approach at the time was pre-Hennigian, but modern inasmuch as he emphasised the importance of features of immature stages and internal anatomy (e.g., alimentary canal, Malpighian tubules). One of his most comprehensive taxonomic works, a revision of Mexican Elmidae (riffle beetles) (Hinton 1940), contains no less than 401 detailed figures depicting larvae and adults and anatomical details of both. Another monograph dedicated to beetles associated with stored products (Hinton 1945) was conceivably inspired by wartime food shortage. Another topic he intensively studied was the respiratory organs of immature stages and adults (e.g., Hinton 1957, 1966). A study dealing with respiratory adaptations of psephenid (water pennies) also included a taxonomic treatment of this highly specialised family (Hinton 1955). Spiracular gills, a larval apomorphy of the suborder Myxophaga (excluding Lepiceridae) (Beutel et al. 1998), were described for the first time by Hinton (1967). He also discovered (and named) a specific defensive device occurring in beetle pupae, the "gin traps" (Hinton 1946a), which are found along the flanks of several families including Tenebrionidae. The pupal stage which is often neglected by coleopterists was one of Hinton's favourite topics, and he introduced a new classification for different types of pupae in another monographic work (Hinton 1946b).

In his later years Hinton was exposed to the Hennigian ideas and in a study on the spiracles of larvae of Myxophaga (Hinton 1967) he implicitly suggested two larval apomorphies occurring only in this suborder: spiracular gills (see above) and a plastron. He used these two features as an argument for separating Myxophaga from the larger suborder Polyphaga, apparently unaware that a separate status of the former group would have to be based not on autapomorphies, but on derived polyphagan features not occurring in myxophagans. Hennig pointed out that Hinton theoretically defended the principles of phylogenetic systematics, but inadvertently relapsed into the typological scheme of argumentation and methodology (Hennig 1969, p. 303: "in die Methodik... der typologischen Systematik zurückgefallen"). A controversy - not only beetles but also concerning "lower lepidopteran" lineages - illustrates Hinton's attitude towards Hennigian systematics. He argued that the "Zeugloptera" ("Protolepidoptera") should be treated as a separate insect lineage, because,otherwise, 
there would be no reason why Trichoptera should not be included in an extended concept of Lepidoptera. N. P. Kristensen, by that time in Hinton's lab as a visitor, pointed out that Hennig (1969) (and Mickoleit [1969]) had refuted this concept (based on lepidopteran autapomorphies), and that the inclusion of "Zeugloptera" in Lepidoptera would by no means affect the status of caddisflies as a separate order. To this Hinton responded with the brief, almost dismissive statement: "Ah, Hennig is a dipterist!" (N. P. Kristensen, pers. comm.). A classic, and yet often overlooked study by Hinton (1977) that should be read by all students of entomology is his short contribution on insect enabling mechanisms, which highlights features (key innovations) that have lead insects to achieve a high diversity. It encapsulates Hinton's broad knowledge of entomology and his intense interest in morphology and physiology that mirror Darwin's intentions to describe diversity in an evolutionary framework based on natural selection.

\section{Russian paleontologists and Lagerstätten and fossil beetles in phylogenetic reconstruction}

It was pointed out by Ghiselin (1991) that Darwin was not only a "great evolutionary anatomist and physiologist" but also "a geologist of the first rank". There is little doubt that he would have been greatly interested in the coleopteran fossil record. However, in Darwin's time virtually nothing was known on beetle fossils and even with the appearance of Handlirsch's work (1908) complete fossils with visible taxonomic features were almost non-existent (Lawrence et al. 1995). Ponomarenko (1995) noted that "the status of paleocoleopterology has not improved in recent times". Even though it may be true that fossils are often neglected by coleopterists, this statement appears over pessimistic as the number of known beetle fossils and paleontological data is remarkable (see e.g., Rasnitsyn and Quicke 2002). This is mainly due to the intensive work of Russian paleontologists such as A. V. Martynov, B. B. Rohdendorf, V. V. Zherikin A. G. and A. G. Ponomarenko (e.g., Ponomarenko 1969, 1977; see Rasnitsyn and Quicke 2002) and the tremendously rich fossil record of regions formerly belonging to the Soviet Union. The oldest known beetles were found in Moravia (Kukalová 1969) but members of the same archaic family Tshekardocoleidae were found in Lower Permian Lagerstätten in the Ural Region (Ponomarenko 1995). The most complete succession of Upper Permian beetles is from different localities in the Kusnezk Basin, the largest described Triassic assemblage is from the Madygen Formation in South Fergana in Central Asia (diverse undescribed species are preserved in Triassic deposits of Australia, South Africa, and the USA), and one of the most important Jurassic localities is the Karatau in South Kazakhstan (Ponomarenko 1969, 1995).

The limited appreciation of fossil beetles by western coleopterists has different reasons. Political and linguistic isolation have probably played a role, and the Russian works were comparatively difficult to obtain. Another factor may have been the nomenclature on the ordinal level used by Russian paleontologists (e.g., Rasnitsyn and Quicke 2002), which is radically different from western classifications (e.g., Cohors Scarabaeiformes $=$ Endopterygota [Holometabola], Scarabaeidae = Coleoptera). Meanwhile, it is often thought by neontologists that fossils lack all of the characters needed for phylogenetic placement, but as sources of characters fossils, especially those in amber provide an enormous amount of information for distribution of characters and dating lineages.

Even though beetle fossils were discussed by Hennig (1969) and Crowson (e.g., 1981) they did not play an important role in the phylogenetic reconstruction (and classification) of Coleoptera outside 
of Russia (see below). The first cladistic study with a numerical approach including Permian and Mesozoic beetle fossils was published only recently (Fig. 3; Beutel et al. 2008). In agreement with Hennig (1969), it demonstrated that Archostemata as defined earlier (e.g., Ponomarenko 1969) are a taxonomic waste basket, and that all Permian beetle lineages (and Triadocupedinae) belong in the stem group of Coleoptera. It also demonstrated that despite missing entries in data matrices, it is better to include extinct taxa, than to analyse Recent taxa first and add fossils into appropriate stem lineages ("if at all") as suggested by Ax (1987). The procedure suggested by Ax (1987) is a non numerical approach in both steps of the character evaluation (or at least in the second). It perpetuates wrong interpretations of character evolution and wrong branching patterns, which may result from the exclusion of fossils (Beutel et al. 2008).

In this paleontological context, the concept of monophyly of Rasnitsyn and Quicke (2002) is explicitly used in a "broader sense" to include paraphyletic taxa ("...monophyly s.l. is definable through possession of a single ancestral line beyond its limits"). This concept differs distinctly from the Hennigian or cladistic approach. The statement "that the myxophagan families must be put into the Archostemata if Micromalthus is an archostematan beetle" is apparently based on a non-cladistic approach. The monophyly of Archostemata including Micromalthidae (but excluding Myxophaga) and of a myxophagan-polyphagan clade was clearly supported in cladistic studies with an extensive morphological data set (Beutel and Haas 2000; Beutel et al. 2008; Friedrich et al. 2009). A. G. Kirejtshuk (1991) postulated "considerable defects of many versions" of cladistic procedures due to the unreliability of structural features. He suggested the use of the "evolution of mode of life" not only for testing phylogenetic hypotheses, but also as the base for reconstructing "the past of groups and the biota as a whole" (Kirejtshuk 1991). There have been other healthy criticisms of cladistic analysis in Russian systematics literature (Zherikhin 1999). However, Kirejtshuk's methodology remains unclear and lacks rigor. His phylogenetic diagram of major groups of beetles (including fossil lineages) does not really show phylogenetic relationships (Kirejtshuk 1991: fig. 1): Adephaga are connected with Myxophaga ("Sphaeriiformia") and an isolated lineage called Schizophoriformia by interrupted lines and Archostemata and Polyphaga are not linked to any other group.

\section{The rise of cladistics and the Third Synthesis}

The quantitative phylogenetic methods used for analysing morphological characters, that began mainly with phenetic methods in the 1960s (e.g., Hull 1988; Grimaldi and Engel 2005), were firmly underway by 1980 s to what is now standard modern cladistics. The main features distinguishing it from the Hennigian approach is a numerical evaluation following the principle of parsimony (usually with cladistic computer programs) and the a posteriori assessment of the character polarity (rooting of the cladogram) (see e.g., Forey et al. 1992).

Whereas an in depth morphological exploration of specific character systems was attempted in many Hennigian studies on beetles (e.g., Burmeister 1976; Bils 1979), the endeavour to include as many characters (and character systems) as possible is characteristic for the cladistic approach. Most current systematists agree that more characters and different types of data yield more solid phylogenetic reconstructions than small, limited data sets. Whether data sets (e.g., larval/adult features, morphological/molecular data) should be analysed simultaneously ('total evidence') or 
separately ('consensus') is discussed controversially (see e.g., Levasseur and Lapointe 2001). The latter approach would have been referred to as reciprocal enlightenment by Hennig. Separate and combined data sets were analysed in studies of Staphyliniformia (Beutel and Leschen 2005a) and other groups (e.g., Leschen et al. 2005). The relative importance of immature and adult characters was recently evaluated by Meier and Lim (2009).

It is an intriguing question how Darwin would have responded to an ongoing debate among cladists whether or not 'the assumption of descent with modification' is required to justify cladistics (e.g., Brower 2000). However, most systematists employing phylogenetic methods would agree that our business is to recognise monophyletic groups which are in turn based on shared, derived characters that are synonymous with features that reveal the antiquity of descent as Darwin had intended.

Several "schools" of beetle systematics had developed (e.g., George Ball's program at the University of Alberta, Edmonton, Canada) in the last decades of the $20^{\text {th }}$ century and the use of cladistics brought a "Third Synthesis" in Coleoptera classification. While great strides have been made in beetle classifications, including some of the most diverse groups, such as Staphylinidae (Newton and Thayer 1995) and weevils (e.g., Kuschel 1995; Oberprieler et al. 2007), it appears that coleopterists of today are still scraping the surface of an unimaginable diversity. Organising this into a natural classification has been a major industry for the Third Synthesis, which has been influenced significantly by the outstanding coleopterist John F. Lawrence. Lawrence began work at University of California, Berkeley, then after graduation took a job as curator at Harvard University, and then took a post at the Australian National Insect Collection in the mid-1970s until retirement in 1999 (Newton et al. 2000), and who continues to produce significant contributions. Assuming the role of historians, it is easy to discuss Lawrence as a contemporary because our memories are fresh and in real time.

Like Darwin's and Crowson's, Lawrence's work is synthetic and is focussed on developing natural classifications, while at the same time producing informative descriptions and keys to higher taxa (e.g., Lawrence 1982). While Lawrence published several synthetic studies as sole author (e.g., on Archostemata (Lawrence 1999), Elateriformia (Lawrence 1988), and Tenebrionoidea (Lawrence 1977)), he excelled by cooperating with others. Among the synthetic works were the classifications he developed with Alfred Newton (Lawrence and Newton 1982, 1995), whom he influenced during the Harvard years along with Newton's partner Margaret Thayer (Thayer and Newton are a tour de force of staphylinoid Coleopterology). The Australian Beetles (Lawrence and Britton 1994), largely extracted from Insects of Australia (Lawrence and Britton 1991), preceded the larval and adult electronic keys produced CD-ROMs (Lawrence et al. 1999a, b) that covered world Coleoptera. Lastly, work on beetle hind wing veins by Lawrence and Jarmila Kukalová-Peck (e.g. Kukalová-Peck and Lawrence 2004) were also significant because of the detailed comparative approach and the refinement in wing vein terminology.

Meanwhile, other contributions to the theory of systematics and cladistic methods continue to use Coleoptera as model systems. Coleopterists, such as David Maddison working on character evolution (Maddison et al. 1984; Maddison and Maddison 1992; Maddison 1994), James Liebherr working on biogeography and island radiations (Liebherr 1988; Liebherr and Hajek 1990; Liebherr and Zimmerman 1998), Brian Farrell working on host-plant interactions (Mitter et al. 1988; Farrell 1998; 
Marvaldi et al. 2002) and others are continually contributing the advancement of beetle systematics and evolutionary biology in the spirit of Darwin and Crowson.

\section{Molecular systematics}

Darwin would have been thoroughly amazed at the post-modern enterprise of molecular biology that penetrates all biological disciplines from developmental biology to taxonomy. The rise of molecular systematics, started comparatively late in studies of Coleoptera (see Caterino et al. 2000 for an overview) and, for example, the two volume Festschrift celebrating the $80^{\text {th }}$ birthday of Roy A. Crowson (Pakaluk and Ślipiński 1995) did not contain a single molecular contribution.

Here we restrict our discussion to the use of molecular data in phylogenetic reconstruction and do not review studies of population genetics. Molecular studies on Coleoptera began with modest taxon samplings and amounts of DNA sequence data. In 1991, one of the first PCR (polymerase chain reaction) of beetle material was carried out by Alfried Vogler (now at The Natural History Museum, London), one of the pioneers of beetle molecular systematics. An early phylogenetic study was on the relationships of four bark weevil species of the Pissodes strobi group (Boyce et al. 1994). Mitochondrial DNA sequences were evaluated with different analytical methods (parsimony, neighbour-joining). The results contradicted earlier hypotheses based on morphology, allozyme and cytogenetic data, and the authors concluded that "mitochondrial and nuclear genes have evolved in distinctly different manners". Vogler and co-workers published several studies dealing phylogeny of tiger beetles (Cicindelinae) based on 18S rDNA and mitochondrial DNA sequences and the analysis of a total of 912 nucleotides sequenced for 30 terminal taxa (Vogler and Pearson 1996) resulted in an evolutionary scenario for the subfamily with nocturnal forms living in leaf litter as ancestral. Other studies from this London-based research group were mainly exclusively based on 18S rRNA (e.g., Shull et al. 2001; Ribera et al. 2002; Caterino et al. 2002) but the taxon sampling was extensive. The last of these studies was focussed on the subordinal relationships within Coleoptera. The single most parsimonious solution after enforcing a monophyletic topology of Coleoptera and all its suborders supported a basal position of Archostemata as suggested by Crowson (1955) and others (e.g., Beutel and Haas 2000); but, in contrast to all other hypotheses, a sistergroup relationship between the large suborders Adephaga and Polyphaga. The trees without enforced topology displayed highly implausible results such as a polyphyletic Myxophaga, with Microsporus (Sphaeriusidae) as the sistergroup of Diptera (including Strepsiptera). It was pointed out by the authors that 18S rDNA alone may not provide sufficient information to solve the addressed questions.

Important developments in molecular systematics in the last decade were improved technical facilities (e.g., automatic sequencing) and increased computational power (e.g., "Beowulf" parallelcomputing-cluster). This has resulted in an impressive increase in the amount of sequence data and taxa included in analyses. Hunt et al. (2007) analysed three genes and nearly 1900 species covering ca. $80 \%$ of the extant beetle families.

A new analytical approach developed in the American Museum of Natural History was POY (Phylogenetic Analysis of DNA and other Data using Dynamic Homology) (Wheeler et al. 1996-2003). The alignment and parsimony analyses, which are carried out separately in the traditional approach, are implemented in a single simultaneous step, thus also subjecting the former step to the principle of 
parsimony. POY is used in some hexapod and beetle studies (e.g., Caterino and Vogler 2002 [alongside with traditional analyses]; Ribera et al. 2002). Problems with the POY approach is that it may be less precise than other methods (Ogden and Rosenberg 2007) and that the obtained direct optimization alignment may not reflect the true homology of sequences (Kjer et al. 2007). The use of structural information to identify homologous positions of rDNA sequences apparently has a great potential to lead to better alignments and phylogenetic results (Kjer et al. 2007). Another relatively new analytical approach, Bayesian inference (e.g., Huelsenbeck et al. 2002), utilizes Markov Chain Monte Carlo (MCMC) simulation to produce a posterior probability distribution. Like maximum likelihood it requires an evolutionary model chosen prior to the analysis. The Bayesian approach was mainly used for analyses of molecular data (Lewis 2001), but also is now being used in some morphology-based studies (e.g., Leschen and Buckley 2006; Friedrich et al. 2009).

The most extensive molecular investigation of beetle phylogeny presently available is the above mentioned multi-authored study by Hunt et al. (2007). Based on a dated phylogeny, the authors postulate that the success of beetles is due to high survival of lineages and sustained diversification in a variety of niches, and not by exceptional net diversification rates or a predominant role of herbivory and the Cretaceous rise of angiosperms (Hunt el al. 2007). Considering that a number of groupings in the tree are unsupported by the data, problematic, or even extremely unlikely (e.g., ant-like stone beetles ["Scydmaenidae"] widely separated from Staphylinidae; see Grebennikov \& Newton 2009: "Goodbye Scydmaenidae..."), these conclusions should be taken with some caution. A promising approach followed by Marvaldi et al. (2009) is an annotated alignment based on secondary structure information (see above), which in turn, provides improved rRNA structure (see also Kjer et al. 2007). The analyses of the data yielded a convincing phylogeny for the extremely species rich cucujiform lineages Chrysomeloidea and Curculionoidea (Phytophaga).

Studies in beetle systematics with combined morphological and molecular data are still very rare. A recent analysis of hydrophiloid relationships (Bernhard et al. 2009) with comprehensive molecular data (6 genes) and 160 morphological characters did not result in the expected breakthrough. The incongruent results in analyses with different weighing schemes and analytical methods (Bayesian inference, parsimony) reflected different competing hypotheses in earlier studies (e.g., Hansen 1991; Beutel 1999).

There is no doubt that phylogenetic reconstruction based on molecular data is a valuable tool and that it has turned out as extremely useful in reconstructing the phylogenies of different groups of insects and other groups of organisms (e.g., Lo et al. 2000: monophyletic origin of wood feeding cockroaches [Cryptocercus] and termites; Fleck et al. 2008: Anisoptera). However, it can be said that its application by coleopterists did not lead to really new, well founded insights in high level phylogeny so far. Aside from this, it is evident that even a molecular tree perfectly reflecting the phylogeny of beetles would remain unsatisfying without a solid morphological background. A profound understanding of the evolution of Coleoptera is not possible without a detailed knowledge of morphological transformations in different stages and on different taxonomic levels. Natural selection, the driving evolutionary factor identified by Darwin, takes effect on the level of the phenotype interacting with the environment with its morphological structures. 


\section{Modern morphological techniques}

In the "age of molecular phylogenetics", the detailed study of insect and beetle morphology may appear futile to some systematists. However, as it is the structural features which are exposed to natural selection in the Darwinian sense (see above), it appears impossible to us to understand the evolution of a group without knowing the morphological transformations that took place in the phylogeny. Moreover most systematists agree that most reliable results are obtained with a combination of molecular and morphological data (see below: Tree of Life). During the last years, this changed attitude among systematists and innovative technologies have triggered a remarkable renaissance in insect anatomy (Beutel and Friedrich 2008).

Whereas the anatomical study of beetles was impeded for a long time by the strong degree of sclerotisation, the highly variable and often attractive surface sculpturing made them superb objects for scanning electron microscopy (SEM). This technique is of very limited use for internal soft parts but ideal for the documentation of surface structures including that of insect eggs, as highlighted by Hinton (1981). As pointed out in Beutel and Friedrich (2008) it is conceivable that the extensive use of SEM has contributed to the decline of insect anatomy in the late $20^{\text {th }}$ century. Visually attractive SEM images can be obtained in much shorter time than for instance complex drawings based on microtome sections.

A combination of different traditional and innovative techniques was applied in recent projects focussed on basal branching events within Coleoptera (Beutel et al. 2008; Friedrich et al. 2009). Problems arising from the hard cuticle have been solved by the use of new embedding media (e.g., Araldite) and diamond knives, and $\mu$-computer tomography ( $\mu-\mathrm{CT}$ ), has turned out as extremely useful (Fig. 2). This innovative technique is non-destructive, largely artefact free, and the images are perfectly aligned (see Hörnschemeyer et al. 2002). Image stacks of high quality can be obtained within few hours. The maximum resolution is presently ca. $1 \mu \mathrm{m}$.

A disadvantage compared to histology is that usually different tissues only show very slightly different gray tones (e.g., Friedrich et al. 2008; Friedrich and Beutel, 2008). However, a good differentiation between cuticle and different soft parts (musculature, nervous system, digestive tract etc.) can be obtained with stable beams with relatively low energy (Fig. 4) (Friedrich et al. 2008; Friedrich and Beutel 2008). Microtome sectioning and $\mu$-Ct are closely linked with another innovation applied in beetle morphology since about ten years - computer-based three dimensional reconstructions. With a combination of modern software programs (e.g., Amira, Imaris, Maya) high quality 3-D models can be obtained in a minimum of time (see e.g., Beutel and Friedrich 2008; Friedrich and Beutel 2008).

The optimised combined applications of modern morphological techniques are not only a qualitative improvement in the documentation and visualisation of structural features. They facilitate the understanding of complex 3-dimensional structures and greatly increase the efficiency of acquiring reliable morphological data. This allows further reconciliation of the approach used by morphologists like Mickoleit with that of modern cladistics to treat as many taxa and characters as possible. 


\section{Recent discoveries}

It is commonly known among entomologists that the discovery of new species of beetles is a rather common event but the discovery of new higher ranking taxa is a much rarer event. A considerable number of new families were discovered in the last decades - findings which would probably have electrified Charles Darwin. Here we mention a few.

Crowsoniella relicta Pace, the single species of the family Crowsoniellidae, was noted as "the most remarkable and unexpected addition to the European coleopterous fauna for a very long time" by Crowson (1976). It is the only extant representative of the archaic relict group Archostemata in Europe. The type series of the small beetle species was discovered in the 1970s in Central Italy (Pace 1975) and no more specimens were collected since then. The biology and immature stages are completely unknown.

The first species of the new adephagan family Aspidytidae (Ribera et al. 2002; Balke et al. 2003) was discovered in China by D. Wrase and M. Schüle in 1995 and a second species in South Africa by I. Ribera and A. Cieslak six years later. Both species live in hygropetric habitats and have secondarily abandoned aquatic habit. Another highly unusual hygropetric adephagan beetle was discovered in 1985 in Venezuela by Paul Spangler and co-workers. The species is extremely small and forms a monotypic family Meruidae (Spangler and Steiner 2005). It was demonstrated with morphological and molecular data that Meruidae and Aspidytidae both belong to the dytiscoid complex of Adephaga (Balke et al. 2008).

Arguably the most obscure beetle ever discovered is Sikhotealinia shiltsovae (Fig. 5). The species collected in the Russian Far East may be referred to as a "phantom" in beetle evolution. The only known single female specimen was found dead at a river's edge (Lafer 1996) and absolutely nothing is known about the original area of distribution, the habitat, the biology, and the immature stages. The species is apparently closely related with the Jurassic genus †Jurodes and was transferred to the family Jurodidae by Kirejtshuk (2000). The phylogenetic affinities are still uncertain (see Beutel et al. 2008). Sikhotealinia displays an intriguing mixture of archostematan and polyphagan features. The discovery of more specimens and an intensive investigation of the taxon may greatly contribute to the understanding of basal branching events in Coleoptera in the future.

Aside from extant beetles recently discovered it is important to note that Cretaceous amber fossils from Lebanon, Spain, Myanmar, New Jersey and other regions have greatly contributed to the knowledge of the Mesozoic beetles diversity (e.g., Grimaldi \& Engel 2005). The life-like fidelity of the preservation renders them also highly valuable for exploring phylogenetic relationships in Coleoptera. Like Willy Hennig, who intensively studied fossil flies from the Tertiary, Darwin doubtlessly appreciated the value of Baltic amber fossils. However, like his contemporaries he was certainly not aware of much older amber dating back to the Mesozoic.

\section{Tree of life and the Handbook of Zoology}

The term 'Tree of Life' was coined by Darwin in "On the Origin of Species" (Darwin 1959: p. 182). It was adopted for a web-based project aiming at an interactive presentation of phylogenetic relationships of all groups of organisms (http://tolweb.org/tree/) and also for the extensive phylogenetic project Assembling the Tree of Life, which is sponsored by the National Science Foundation, USA and 
has the ambitious goal of reconstructing the evolutionary origins of all living things. The Beetle Tree of Life (BToL) is one branch of this initiative and a coordinated effort of research groups mainly focussed on molecular data and specialists for specific groups and morphologists. Sequence data of up to ten nuclear genes will be compiled by the research teams of B. D. Farrell (Museum of Comparative Zoology, Harvard University) and D. Maddison (University of Arizona; see Wild and Maddison 2008) and the complete mitochondrial genome has been sequenced in the lab of M. F. Whiting (Brigham Young University; see Sheffield et al. 2008). The leading researchers of the morphological part are John Lawrence (see above) and A. S. Ślipiński (CSIRO, Canberra, Australia), a coleopterist who has made remarkable contributions to the study of beetle phylogeny and evolution in the last decades (e.g., Pakaluk and Ślipiński 1995). The first objective of the project is to assess the phylogenetic relationships among beetle suborders, superfamilies, families, and subfamilies using morphological characters of larvae and adults and molecular data in three tiers. The $1^{\text {st }}$ Tier project addresses "deep relationships" using 75 terminal taxa that will be sampled for morphology and $23 \mathrm{~kb}$ of DNA sequence data. The $2^{\text {nd }}$ Tier project is at the superfamily and family level and comprises 300 taxa (morphology and $\sim 11.8 \mathrm{~kb}$ of mitochondrial and nuclear DNA). About 600 terminals will be analysed in the $3^{\text {rd }}$ Tier projects based exclusively on DNA sequence data. The hitherto largest vouchered morphological database will be established and bioinformatics tools will be developed freely available on the www.

BToL is the most extensive phylogenetic investigation in the history of the study of beetles. Whether it will be successful in creating a well founded system of Coleoptera reflecting the evolution in the Darwinian (or Haeckelian) sense is still an open question. Whereas the phylogenies of the small or medium sized suborders Archostemata, Myxophaga and Adephaga are already quite well understood (e.g., Beutel et al. 1998; Beutel et al. 2008; Friedrich et al. 2009), it is uncertain whether BToL will solve the longstanding problems in the phylogeny of the extremely speciose and complex Polyphaga (ca. 150 families, ca. 330.000 spp.), notably the relationships of numerous families assigned to the series Elateriformia and the non-phytophagan cucujiform superfamilies. To obtain a complete or nearly complete picture or scenario of the evolution of an extremely diverse and complex group like Polyphaga or the entire Coleoptera in the near future may be overoptimistic.

Much remains to be accomplished in the years ahead and much of what has been done in beetle systematics up to present is being treated in the Coleoptera portion of the Handbook of Zoology. This is a multi-authored series that is edited by two of us (RGB, RABL) and each chapter includes a review of adult and larval characters, distribution, biological information and reviews of phylogeny and classification. Volume I (Adephaga, Myxophaga, and part of the Elateriformia) has been published (Beutel and Leschen 2005b), while volume II (most of the Polyphaga) will be published this year and volume III (Phytophaga) will be published subsequently. Most chapters are covered by specialists, but the project clearly revealed the sobering fact that many families lack contemporary experts. It is our hope that the Handbook will foster new students and as participants in the Third Synthesis of beetle systematics we remain positive that the search for natural classifications will continue using new methods, by examining new character systems (in the broadest sense), and by producing new classifications to discover the Coleoptera tree of life and continue Darwin's warhorse spirit of enthusiasm for beetles. 


\section{Acknowledgements}

It is a pleasure for us to express our gratitude to E. and G. Mickoleit (Zoologische Schausammlung Tübingen) and N. P Kristensen (Zoologisk Museum, Copenhagen) for detailed and valuable background information. We also wish to thank Prof. Dr. Olaf Breidbach and Dr. Rita Schwertner (Ernst Haeckel Haus, Jena) for information, Ronald Bellstedt (Museum der Natur, Gotha) for pictures (Fig. 1) (permission granted to RB by NHM), and Prof. Dr. R. E. Roughley (University of Manitoba for valuable suggestions). Micro-CT data were obtained at DESY (Hamburg; project number I-20070032). This and technical support by Dr. Felix Beckmann is also gratefully acknowledged.

\section{Literature}

Anton E, Beutel RG (2006) On the head morphology of Lepiceridae (Coleoptera: Myxophaga) and the systematic position of the family and suborder. Eur J Entomol 103:85-95

Ax P (1987) The Phylogenetic System: The Systematization of Organisms on the Basis of their Phylogenesis. Wiley, New York

Baehr M (1975) Skelett und Muskulatur des Thorax von Priacma serrata Leconte (Coleoptera, Cupedidae). Z Morph Tiere 81:55-101

Balke M, Ribera I, Beutel RG (2003) Dytiscoidea incertae sedis: Aspidytes wrasei gen.n, sp.n. - An enigmatic new adephagan beetle discovered in Shaanxi, China (Coleoptera). Water Beetles of China III, Vol. LII:53-66

Balke M, Ribera I, Beutel RG, Viloria A, Garcia M, Vogler AP (2008) Systematic placement of the recently discovered beetle family Meruidae (Coleoptera: Dytiscoidea) based on molecular data. Zool Scr 37:647-650

Barrett PH (1977) The Collected Papers of C. Darwin. 2 vols. University of Chicago Press, Chicago

Belkaceme T (1991) Skelet und Muskulatur des Kopfes und Thorax von Noterus laevis Sturm. Ein Beitrag zur Morphologie und Phylogenie der Noteridae (Coleoptera: Adephaga). Stuttg Beitr Naturk (A) 462:1-94

Bernard D, Ribera I, Komarek A, Beutel RG (2009). Phylogenetic analysis of Hydrophiloidea (Coleoptera, Polyphaga) based on molecular data and morphological characters of adults and immature stages. Ins Syst Evol 40:3-41

Beutel R (1986) Skelet und Muskulatur des Kopfes und Thorax von Hygrobia tarda (Herbst). Ein Beitrag zur Klärung der phylogenetischen Beziehungen der Hydradephaga (Insecta: Coleoptera). Stuttg Beitr Naturk (A) 388:1-54

Beutel RG (1999) Morphology and evolution of the larval head structures of Hydrophiloidea and Histeroidea (Coeloptera: Staphylinidae). Tijdschr Entomol 142:9-30

Beutel RG, Balke M, Steiner WE (2006) On the systematic position of Meruidae (Coleoptera, Adephaga) and the phylogeny of the smaller hydradephagan families. Cladistics 22:102-131

Beutel RG, Friedrich F (2008) A renaissance of insect morphology - $\mu-\mathrm{Ct}$ and other innovative techniques. DGaaE Nachr 22:5-8

Beutel RG, Ge S-Q, Hörnschemeyer T (2008) On the head morphology Tetraphalerus, the phylogeny of Archostemata and the basal branching events in Coleoptera. Cladistics 23:1-29 
Beutel RG, Haas F (2000) Phylogenetic relationships of the suborders of Coleoptera (Insecta). Cladistics 16:103-141

Beutel RG, Leschen RAB (2005a) Phylogenetic analysis of Staphyliniformia (Coleoptera) based on characters of larvae and adults. Syst Entomol 30:510-548

Beutel RG, Leschen RAB (eds) (2005b) Coleoptera, Vol. I. Morphology and Systematics (Archostemata, Adephaga, Myxophaga, Polyphaga partim). Handbook of Zoology Vol. IV, Arthropoda: Insecta. De Gruyter, Berlin, New York

Beutel RG, Maddison DR, Haas A (1998) Phylogenetic analysis of Myxophaga (Coleoptera) using larval characters. Syst Entomol 24:1-23

Bils W (1976) Das Abdomenende weiblicher, terrestrisch lebender Adephaga (Coleoptera) und seine Bedeutung für die Phylogenie. Zoomorph 84:113-193

Bitsch J (1966) L'évolution des structures céphaliques chez les larves de coléoptères. Ann Soc entomol Fr (N.S.) 2:255-324

Bøving AG, Craighead FC (1931) An illustrated synopsis of the principal larval forms of the order Coleoptera. Entomol Am 11:1-125

Boyce TM, Zwick ME, Aquadro, CF (1994) Mitochondrial DNA in the bark weevils: phylogeny and evolution in the Pissodes strobi species group (Coleoptera: Curculionidea). Mol Biol Evol 11:183-194

Brauer F (1869) Betrachtungen über die Verwandlungen der Insecten im Sinne der Deszendenztheorie. Verh Zool-Bot Ges Wien 19:299-318

Brower AVZ (2000) Evolution is not a necessary assumption of cladistics. Cladistics 16:143-154

Burmeister EG (1976) Der Ovipositor der Hydradephaga (Coleoptera) und seine phylogenetische Bedeutung unter besonderer Berücksichtigung der Dytiscidae. Zoomorph 85:165-257

Cain AJ (1957) Deductive and inductive methods in post-Linnean taxonomy. Proc Linn Soc Lond 170:185-217

Caterino MS, Shull VL, Hammond PM, Vogler AP (2002). Basal relationships of Coleoptera inferred from 18S rDNA sequences. Zool Scr 31:41-49

Caterino MS, Cho S, Sperling FAH (2000) The current state of insect molecular systematics: A thriving tower of Babel. Annu Rev Entomol 45:1-54

Caterino MS, Vogler AP (2002) The phylogeny of the Histeroidea (Coleoptera: Staphyliniformia). Cladistics 18:394-415

Clare AS, Evans LV (eds) (2000) Marine Biofouling an International Symposium, Plymouth 1999. Spec Iss Biofouling 16:81-365

Crowson EA (1995) Life with R. A. Crowson. In: Pakaluk J, Ślipiński SA (eds) Biology, Phylogeny, and Classification of Coleoptera: Papers Celebrating the $80^{\text {th }}$ Birthday of Roy Crowson. Muzeum $\mathrm{i}$ Instytut Zoologii PAN, Warszawa, pp. 5-10

Crowson RA (1938) The metendosternite in Coleoptera: a comparative study. Trans R Entomol Soc Lond 94:273-310

Crowson RA (1944) Further studies on the metendosternite in Coleoptera: a comparative study. Trans R Entomol Soc Lond 87:397-416 
Crowson RA (1950) The classification of the families of British Coleoptera. Entomol mon Mag 86:149 -

171, 274-288, 327-344

Crowson RA (1954) The classification of the families of British Coleoptera. Entomol mon Mag 90:57-

63

Crowson RA (1955) The natural classification of the families of Coleoptera. Nathaniel Lloyd \& Co., Ltd., London

Crowson RA (1959) Studies on the Dermestoidea (Coleoptera), with special reference to the New Zealand fauna. Trans R Entomol Soc Lond 111:81-94

Crowson RA (1960) The phylogeny of Coleoptera. Ann Rev Ent 5:111-134

Crowson RA (1964) A review of the classification of Cleroidea (Coleoptera), with descriptions of two genera of Peltidae and of several new larval types. Trans R Entomol Soc London 116: 275327

Crowson RA (1970) Classification and Biology. Heinemann Educational Books Ltd, London

Crowson RA (1973) Further observations on Phloeostichidae and Cavognathidae, with definitions of new genera from Australia and New Zealand. Coleopt Bull 27:54-62

Crowson RA (1975) Anti-Darwinism among the molecular biologists. Nature 254:464

Crowson RA (1976) The systematic position and implications of Crowsoniella. Boll Mus Civ Stor Nat Verona 2:456-463

Crowson RA (1981) The biology of Coleoptera. Academic Press, London

Crowson RA (1991) A critique of current cladistics. J. Nat Hist 25(1):3-5

Crowson RA (1982) Computers versus imagination in the reconstruction of phylogeny. In: Joysey KA, Friday AE (eds) Problems of phylogenetic reconstruction. Academic Press, London, pp. 245-255

Darwin C (1845) Journal of researches into the natural history and geology of the countries visited during the voyage of H.M.S. Beagle round the world, under the Command of Capt. Fitz Roy, R.N. 2d edition. John Murray, London

Darwin C (1851) A monograph on the sub-class Cirripedia, with figures of all the species. The Lepatidae; or, pedunculated cirripedes. Ray Society, London

Darwin C (1859) On the origin of species by means of natural selection or the preservation of favoured races in the struggle for life. John Murray, London

Darwin C (1871) The descent of man, and selection in relation to sex. John Murray, London.

Desmond A, Moore J (1991) Darwin. The Life of a Tormented Evolutionist. W. W. Norton \& Company, New York, London.

Dönges J (1954) Der Kopf von Cionus scrophulariae L. (Curculionidae). Zool Jb Anat 74:1-76

v Emden FI (1932) Die Larven der Callirhipini, eine mutmaßliche Cerophytum-Larve und FamilienBestimmungstabellen der Larven der Malacodermata-Sternoxia-Reihe (Coleoptera). Bull Ann Soc R Entomol belg 72:199-259

Erwin T (1988) The tropical forest canopy. The heart of biotic diversity. In Wilson EO (ed.) Biodiversity. Stanford University Press, Stanford, pp. 123-129

Farrell BD (1998) "Inordinate fondness" explained: Why are there so many beetles? Science 281:553- 
Finston TL, Peck SB, Perry RB (1997) Population density and dispersal ability in Darwin's darklings: flightless beetles of the Galápagos Islands. Pan-Pac Entomol 73:110-121

Fleck G, Ullrich B, Brenk M, Wallnisch C, Orland M, Bleidissel S, Misof BA (2008) Phylogeny of anisopterous dragonflies (Insecta, Odonata) using mtRNA genes and mixed nucleotide/doublet models. J Zool Syst Evol Res 46:310-322

Forbes WTM (1922) The wing-venation of the Coleoptera. Ann Entomol Soc Am 15:328-345

Forbes WTM (1926) The wing folding patterns of Coleoptera. J NY entomol Soc 34:42-68, 91-139

Forey PL, Humphries C, Kitching JIJ, Scotland RW, Siebert DJ, Williams DM (eds) (1992) Cladistics: a Practical Course in Systematics. Vol. 10. Clarendon Press, Oxford

Friedrich F, Beutel RG (2008) Micro-computer tomography and a renaissance of insect morphology. Proc SPIE 7048:1-6

Friedrich F, Farrell BD, Beutel RG (2009). The thoracic morphology of Archostemata and the relationships of the extant suborders of Coleoptera (Hexapoda). Cladistics 24:1-37

Friedrich F, Pohl H, Hünefeld F, Beckmann F, Herzen J, Beutel RG (2008) SR $\mu$ CT-based study of external and internal structures of adults and larvae of Endopterygota (Hexapoda). Hasylab Ann Rep 2007, Hamburg: 1527-1528

Ghiselin MT (1991) Classical and molecular phylogenetics. Boll Zool 58:289-294

Grebennikov V.V., Newton A.F. 2009: Good-bye Scydmaenidae, or why the ant-like stone beetles should become megadiverse Staphylinidae sensu latissimo (Coleoptera). Eur J Entomol 106:275-301

Grimaldi D, Engel MS (2005) Evolution of the Insects. Cambridge University Press, New York Haeckel E (1866) Generelle Morphologie der Organismen, II. Georg Reimer, Berlin

Haeckel E (1874) Anthropogenie oder Entwicklungsgeschichte des Menschen. Gemeinverständliche wissenschaftliche Vorträge über die Grundzüge der menschlichen Keimes- und StammesGeschichte. Wilhelm Engelmann, Leipzig

Haeckel E (1896) Systematische Phylogenie der wirbellosen Thiere (Invertebrata). Zweiter Teil des Entwurfs einer systematischen Phylogenie. Berlin

Haldane JBS (1949) Suggestions as to quantitative measurement of rates of evolution. Evolution $3: 51-56$

Handlirsch A (1908) Die Fossilen Insekten und die Phylogenie der rezenten Formen. Ein Handbuch für Paläontologen und Zoologen. Lieferung 8-9. pp. 1121-1430, vii-ix. W. Engelmann, Leipzig

Hansen M (1991) The hydrophiloid beetles: phylogeny, classification and a revision of the genera (Coleoptera, Hydrophiloidea). Biol Skr Dan Vid Sels 40:1-367

Hennig W (1950) Grundzüge einer Theorie der phylogenetischen Systematik. Deutscher Zentralverlag, Berlin

Hennig W (1966) Phylogenetic Systematics. Univ. Illinois Press, Urbana

Hennig (1969) Die Stammesgeschichte der Insekten. Waldemar Kramer, Frankfurt a.M.

Hinton HE (1934) Two coleopterous families new to Mexico. Pan-Pac Entomol 9:160-162

Hinton HE (1940) A monographic revision of the Mexican water beetles of the family Elmidae. Novit Zool 42:217-396 
Hinton HE (1945) A Monograph of the Beetles Associated with Stored Products. Vol. I. 433 pp. British Museum of Natural History, London

Hinton HE (1946a) The "gin-traps" of some beetle pupae; a protective device which appears to be unknown. Trans R ent Soc Lond 97:473-496

Hinton HE (1946b) A new classification of insect pupae. Proc zool Soc Lond 116:282-328

Hinton HE (1955) On the Respiratory Adaptions, Biology and Taxonomy of the Psephenidae, with Notes on same Related Families (Coleoptera). Proc Zool Soc Lond 125:543-568

Hinton HE (1957) The spiracular gills of insects. Proc X. Int Congr Ent Montreal 1:543-548

Hinton HE (1966) Respiratory adaptations of the pupae of beetles of the family Psephenidae. Phil Trans R Soc London (B) 251:211-245

Hinton HE (1977) Enabling mechanisms. Proc XV Int Congr Ent, Wash: 71-83

Hinton HE (1981) Biology of Insect Eggs. 3 Vols. Pergamon Press, Oxford etc.

Hörnschemeyer T, Beutel RG, Pasop F (2002) Head structures of Priacma serrata Leconte (Coleoptera, Archostemata) inferred from X-ray tomography. J Morph 252(3): 298-314

Huelsenbeck JP, Larget B, Miller RE, Ronquist F (2002) Potential application and pitfalls of Bayesian inference of phylogeny. Syst Biol 51:673-688.

Hull DL (1988) Science as a Process: An Evolutionary Account of the Social and Conceptual Development of Science. University of Chicago Press, Chicago.

Hunt T, Bergsten J, Levkanicova Z, Papadopoulou A, St John O, Wild R, Hammond PM, Ahrens D, Balke M, Caterino MS, Gómez-Zurita J, Ribera I, Barraclough T G, Bocakova M, Bocak L, Vogler AP (2007) A comprehensive phylogeny of beetles reveals the evolutionary origins of a superradiation. Science 318:1913-1916

Jeannel R, Paulian R (1944) Morphologie abdominale des Coléoptères et systématique de l'ordre. Rev franc Entomol 9:65-109.

Jones MRL, Leschen RAB (2008) Beetles in the diet of six species of deep-sea fish. NZ J Zool 35:251253

Kirejtshuk AG (1991) Evolution of mode of life as the basis for division of the beetles into groups of high taxonomic rank. In: Zunino M, Bellés X, Blas $M$ (eds) Advances in Coleopterology. European Association of Coleopterology, Barcelona, pp. 249-262

Kirejtshuk AG (2000) Sikhotealinia zhiltzovae (Lafer, 1966) - Recent representative of the Jurassic Coleopterous fauna (Coleoptera, Archostemata, Jurodidae). Proc Zool Inst RAS 281:21-216

Kjer KM, Gillespie JJ, Ober KA (2007) Opinions on multiple sequence alignment, and an empirical comparison of repeatability and accuracy between POY and structural alignments. Syst Biol 56:133-146

Kolbe HJ (1901) Vergleichend-morphologische Untersuchungen an Coleopteren nebst Grundlagen zu einem System und zur Systematik derselben. Arch Naturgesch 67 (Beih): 89-150, Tafel II-III

Kukalová J (1969) On the Systematic position of the supposed Permian beetles, Tshekardocoleidae, with a description of a new collection from Moravia. Sborn Geol Ved, Rada P Paleont 11:139144

Kukalová-Peck J, Lawrence JF (2004) Relationships among coleopteran suborders and major endoneopteran lineages: Evidence from hind wing characters. Eur J Entomol 101:95-144 
Kuschel G (1995) A phylogenetic classification of Curculionoidea to families and subfamilies. Mem Entomol Soc Wash 14:5-33

Larsén $O$ (1966) On the morphology and function of locomotor organs of the Gyrinidae and other Coleoptera. Opusc Entomol (Suppl) 30:1-241

Latreille PA (1825) Familles Naturelles du Règne Animal. 570 pp. Baillière, Paris.

Lafer GS (1996) Fam. Sikhotealiniidae. In: Lafer PA (ed.), Key to the Insects of the Russian Far East. Vol. III, part 3. Dal'nauka, Vladivostok, pp. 298-302.

Lawrence JF (1977) The family Pterogeniidae, with notes on the phylogeny of the Heteromera. Coleopt Bull 31:25-56

Lawrence JF (1982) Coleoptera. In Parker S (ed.) Synopsis and Classification of Living Organisms. McGraw-Hill, New York, pp. 482-553

Lawrence JF (1988) Rhinorhipidae, a new beetle family from Australia, with comments on the phylogeny of the Elateriformia. Invert Tax 2:1-53

Lawrence JF (1999) The Australian Ommatidae (Coleoptera), with a new species, a putative larva and comments on the suborder Archostemata. Invert Tax 13:369-390

Lawrence JF, Britton EB (1991) Coleoptera (beetles). In CSIRO (ed.) Insects of Australia. 2nd Ed. Vol. 2. Melbourne University Press, Carlton, pp. 543-683

Lawrence JF, Britton EB (1994) Australian Beetles. Melbourne University Press, Carlton

Lawrence JF, Hastings AM, Dallwitz MJ, Paine TA, Zurcher EJ (1999a) Beetle Larvae of the World: Descriptions, Illustrations, Identification, and Information Retrieval for Families and Subfamilies. CD-ROM, Version 1.1 for MS-Windows. CSIRO Publishing, Melbourne

Lawrence JF, Hastings AM, Dallwitz MJ, Paine TA, Zurcher EJ (1999b) Beetles of the World: A Key and Information System for Families and Subfamilies. CD-ROM, Version 1.0 for MS-Windows. CSIRO Publishing, Melbourne

Lawrence JF, Newton AF (1982) Evolution and classification of beetles. Annu Rev Ecol Syst 13:261290

Lawrence JF, Newton AF (1995) Families and subfamilies of Coleoptera (with selected genera, notes, references and data on family-group names). In: Pakaluk J, Ślipiński SA (eds), Biology, Phylogeny, and Classification of Coleoptera: Papers Celebrating the $80^{\text {th }}$ Birthday of Roy Crowson. Muzeum i Instytut Zoologii PAN, Warszawa, pp. 779-1006

Lawrence JF, Ślipiński SA, Pakaluk J (1995) From Latreille to Crowson: a history of the high level of beetles. In: Pakaluk J, Ślipiński SA (eds), Biology, Phylogeny, and Classification of Coleoptera: Papers Celebrating the $80^{\text {th }}$ Birthday of Roy Crowson. Muzeum i Instytut Zoologii PAN, Warszawa, pp. 86-154

Leng CW (1920) Catalogue of the Coleoptera of North America, North of Mexico. John D. Sherman Jr., Mount Vernon, New York

Leschen RAB (1999) Systematics of Convex Nitidulinae (Coleoptera: Nitidulidae): Phylogenetic Relationships, Convexity, and the Origin of Phallalophagy. Invert Tax 13:845-882

Leschen RAB (2000) Roy A. Crowson 1915-1999. NZ Entomol 22:102-104

Leschen RAB, Beutel RG (2005) Elateriformia Crowson, 1960. pp. 427-429. In: Beutel RG, Leschen RAB (eds) Coleoptera, Vol. I. Morphology and Systematics (Archostemata, Adephaga, 
Myxophaga, Polyphaga partim). Handbook of Zoology Vol. IV, Arthropoda: Insecta. De Gruyter, Berlin, New York

Leschen RAB, Buckley TR (2007) Multistate characters and diet shifts: evolution of Erotylidae (Coleoptera). Syst Biol 56:97-112

Leschen RAB, Lawrence JF, Ślipiński SA (2005) Classification of basal Cucujoidea (Coleoptera: Polyphaga), cladistic analysis, keys and review of new families. Invert Syst 19:17-73

Levasseur C, Lapointe F-J (2001) War and peace in phylogenetics: a rejoinder on total evidence and consensus. Syst Biol 50:881-891

Lewis PO (2001) A likelihood approach to estimating phylogeny from discrete morphological character data. Syst Biol 50:913-925

Liebherr JK (1988) Zoogeography of Caribbean Insects. Cornell University Press, Ithaca, New York. $285 \mathrm{pp}$.

Liebherr JK, Hajek AE (1990) A cladistic test of the taxon cycle and taxon pulse. Cladistics 6:39-59

Liebherr JK, Zimmerman EC (1998) Cladistic analysis, phylogeny, and biogeography of Hawaiian Platynini (Coleoptera: Carabidae). Syst Ent 23:137-172

Lo N, Tokuda G, Watanabe H, Rose H, Slaytor M, Maekwa K, Bandi C, Noda H (2000) Evidence form multiple gene sequences indicates that termites evolved from wood-feeding cockroaches. Curr Biol 10:801-804

Maddison DR (1994) Phylogenetic methods for inferring the evolutionary history and processes of change in discretely valued characters. Ann Rev Ent 39:267-292

Maddison WP, Maddison DR (1992) 'MacClade, version 3: Analysis of phylogeny and character evolution'. Sinauer, Sunderland, Mass.

Maddison WP, Donoghue MJ, Maddison DR (1984) Outgroup analysis and parsimony. Syst Zool 33:83-103

Maier W (2008) Zur morphologischen und phylogenetischen Methodologie von Hermann Weber. Entomol Gener 31:113-117

Marren P (2008) Darwin's war-horse: beetle collecting in the 19th-century England. Brit Wildl 19:153159

Marvaldi AE, Sequeira AS, O'Brien CW, Farrell BD (2002) Molecular and morphological phylogenetics of weevils (Coleoptera: Curculionoidea): Do niche shifts accompany diversification? Syst Biol $51: 761-785$

Marvaldi AE, Duckett CN, Kjer KM, Gillespie JJ (2009) Structural alignment of 18 S and 28 S rDNA sequences provides insights into phylogeny of Phytophaga (Coleoptera: Curculionoidea and Chrysomeloidea). Zool Scr 38:63-77

Mayr E (1975) Grundlagen der Zoologischen Systematik. Paul Parey, Hamburg, Berlin

Meier R, Lim GS (2009) Conflict, Convergent evolution, and the relative importance of immature and adult characters in endopterygote phylogenetics. Ann Rev Ent 54:85-104

Mickoleit G (1963) Untersuchungen zur Kopfmorphologie der Thysanopteren. Zool Jb Anat Ontog Tiere 81:101-150

Mickoleit G (1969) Vergleichend-anatomische Untersuchungen and der pterothorakalen Pleurotergalmuskulatur der Neuroptera und Coleoptera. Z Morph Tiere 64:151-178 
Mickoleit G (1973) Über den Ovipositor der Neuropteroidea und Coleoptera und seine phylogenetische Bedeutung. Z Morph Tiere 74:37-64

Minelli A (1993) Biological Systematics: The Stare of the Art, Chapman \& Hall, London

Mitter C, Farrell BD, Wiegmann BM (1988) The phylogenetic study of adaptive zones: Has phytophagy promoted insect diversification? Amer Natural 132:107-128

Newton AF, Thayer MK (1995) Protopselaphinae new subfamily for Protopselaphus new genus from Malaysia, with a phylogenetic analysis and review of the Omaliine Group of Staphylinidae including Pselaphidae (Coleoptera). In: Pakaluk J, Slipinski SA (eds) Biology, phylogeny and classification of Coleoptera: Papers celebrating the 80th birthday of Roy A. Crowson. Muzeum i Instytut Zoologii PAN, Warszawa, pp. 219-320

Newton AF, Matthews EG, Muona J (2000) John F. Lawrence - coleopterist par excellence. Invert Syst 14:721-731

Novotny V, Miller SE, Hulcr J, Drew RAI, Basset Y, Janda M, Setliff GP, Darrow K, Stewart AJA, Auga J, Isua B, Molem K, Manumbor M, Tamtiai E, Mogia M, Weiblen GD (2007) Low beta diversity of herbivorous insects in tropical forests. Nature 448:692-695

Oberprieler RG, Marvaldi A, Anderson R (2007) Weevils, weevils, weevils everywhere. Zootaxa 1668:491-520

Ogden TH, Rosenberg M (2007) Alignment and topological accuracy of the direct optimization approach via POY and traditional phylogenetics via Clustal W +PAUP*. Syst Biol 56:182-193

Pace R (1975) An exceptional endogeous beetle: Crowsoniella relicta N. Gen. N. Sp. of Archostemata Tetraphaleridae from Central Italy. Boll Mus Civ St Nat Verona 2: 445-458

Pakaluk J, Ślipiński SA (eds) (1995) Biology, Phylogeny, and Classification of Coleoptera: Papers Celebrating the $80^{\text {th }}$ Birthday of Roy Crowson. Museum I Instytut Zoologii PAN, Warszawa

de Peyerimhoff P (1933) Les larves des Coleoptères d'apres Böving et Craighead et les grands criteriums de l'ordre. Ann Soc entomol France 102:77-106

Ponomarenko AG (1969) The historical development of archostematan beetles. (in Russian). $\mathrm{Tr}$ paleont Inst Akad Nauk SSSR 125: 1-238

Ponomarenko AG (1977) Suborder Adephaga, etc. pp. 3-104. In: Arnoldy LV, Jerikin VV, Nikritin LM, Ponomarenko AG (eds) Mesozoic Coleoptera (in Russian). Tr Palaeont Inst Akad Nauk SSSR 161: 1-183

Ponomarenko AG (1995) The geological history of beetles. In: Pakaluk J, Ślipiński SA (eds) Biology, Phylogeny, and Classification of Coleoptera: Papers Celebrating the $80^{\text {th }}$ Birthday of Roy Crowson. Museum I Instytut Zoologii PAN, Warszawa, pp. 155-171

Rasnitsyn AP, Quicke DLJ (eds) (2002) History of Insects. Kluwer Academic Publishers, Dordrecht

Reif W, Thomas RDK, Fischer MS (1985) Constructional morphology: The analysis of constraints in evolution dedicated to A. Seilacher in honour of his 60. birthday. Acta Biotheor 34:233-248.

Ribera I, Beutel RG, Balke M, Vogler AP (2002) Discovery of Aspidytidae, a new family of aquatic Coleoptera. Proc R Soc Lond 269:2351-2157

Richards OW, Davis RG (1994) Imm's General Textbook of Entomology. 2 Vols. Chapman \& Hall, London etc.

Risler H (1954) Der Kopf von Bovicola caprae (Gurlt) (Mallophaga). Zool Jb Anat 71: 289-426 
Schiødte JMC (1862, 1883) De metamorphosi Eleutheratormu observations: bidrag til insekternes udviklingshistorie. Naturhist Tidskr (3), 1:193-232, pls 1-10 (1862), 13:415-426, pl 18 (1863).

Sharp D, Muir F (1912) The male genital tube in Coleoptera. Trans Entomol Soc Lond 1912:477-642

Sheffield NC, Song H, Cameron SL, Whiting MF (2008) A comparative analysis of mitochondrial genomes in Coleoptera (Arthropoda: Insecta) and genome descriptions of six new beetles. Mol Biol Evol 25:2499-2509

Shull VL, Vogler AP, Baker MD, Maddison DR, Hammond PM (2001) Sequence alignment of 18S ribosomal RNA and the basal relationships of adephagan beetles: evidence for monophyly of aquatic families and the placement of Trachypachidae. Syst Biol 50:945-969

Simpson GG (1961) Principles of Animal Taxonomy. 247 pp. Columbia University Press, New York

Ślipiński SA, Pakaluk J (1992) Problems in the classification of the cerylonid series of Cucujoidea (Coleoptera). In: Zunino M, Bellés X, Blas M (eds) Advances in Coleopterology. Associacíon Europea de Coleopterololgia, Barcelona, pp. 79-88

Snodgrass RE (1935) Priniciples of Insect Morphology. MacGraw-Hill, London, New York

Spangler PJ, Steiner WE (2005) A new aquatic beetle family, Meruidae, from Venezuela (Coleoptera: Adephaga). Syst Entomol 30:339-357

Tröster G (1987) Skelet und Muskulatur des Kopfes der Larve von Pterostichus nigrita (Paykull) (Coleoptera: Carabidae). Stuttg Beitr Naturk (A) 399:1-23

Verhoeff KW (1923) Beiträge zur Kenntnis der Coleopteren Larven unter besonderer Berücksichtigung der Clavicornia. Arch Naturgesch 89: 1-109, pls I-VII

Vogler AP, Pearson DL (1996) A molecular phylogeny of the tiger beetles (Cicidelidae): Congruence of mitochondrial and nuclear rDNA data sets. Mol Phyl Evol 6:321-338

Wägele J-W (2001) Grundlagen der Phylogenetischen Systematik. Verlag Friedrich Pfeil, München

Wallace AR (1869) The Malay Archipelago. Harper \& Brothers, New York

Weber H (1933) Lehrbuch der Entomologie. Gustav Fischer, Jena

Weber H (1938) Grundriß der Insektenkunde. Gustav Fischer, Jena

Weber H (1955) Stellung und Aufgaben der Morphologie in der Zoologie der Gegenwart. Verh Dt Zool Ges Tübingen 1954. Suppl Zool Anz 18: 137-159

Weber H (1960) Konstruktionsmorphologie. Zool Jb Allg Zool Physiol 68: 1-112

Weber H (1969) Die Elefantenlaus Haematomyzus elefantis Piaget 1869. Zoologica 41: I-VI, 1-154 + 1 pl

Wheeler QD (1995) The “Old systematics": classification and phylogeny. In: Pakaluk J, Ślipiński SA (eds) Biology, Phylogeny, and Classification of Coleoptera: Papers Celebrating the $80^{\text {th }}$ Birthday of Roy Crowson. Museum I Instytut Zoologii PAN, Warszawa, pp. 11-30

Wheeler WC, Gladstein DS, De Laet J (1996-2003) POY. Version 3.0. ftp.amnh.org/pub/molecular/poy (current version 3.0.11). Documentation by Janies, D. and W. Wheeler, W. Commandline documentation by De Laet $\mathrm{J}$ and Wheeler WC

Wild AL, Maddison DR (2008) Evaluating nuclear protein-coding genes for phylogenetic utility in the Coleoptera. Mol Phyl Evol 48:877-891

Zherikhin VV (1999) Cladistics in Palaeontology: Problems and Constraints. Proceedings of the First International Palaeoentomological Conference, Moscow 1998 99:193-199 
Fig. 1. Carabid beetle collected and labelled by Chares Darwin (Holotype). Picture courtesy Ronald Bellstedt, taken at the NHM London.

Fig. 2. Phylogenetic tree (Stammbaum) from Haeckel (1874) (“Anthropogenie").

Fig. 3. Phylogenetic tree (cladogram) showing interrelationships of major coleopteran lineages including stemgroup taxa traditionally assigned to Archostemata. Extinct taxa marked by an asterisk, species rich suborders underlined. From Beutel et al. (2008), modified.

Fig. 4. Omophron limbatum (Carabidae, ground beetles), head and anterior thorax. Volume renders of $\mu$-computer tomography data (scanned at DESY Hamburg). A, Head and thorax, anterolateral view; B, Virtual cross section, posterior head region; C, Virtual sagittal section, lateral view; D, virtual horizontal section. Scale bar: $250 \mu \mathrm{m}$.

Fig. 5. Sikhotealinia zhiltzovae Lafer, 1996 ("most mysterious representative of beetles"). From: http://www.zin.ru/animalia/coleoptera/images/sources, modified. 